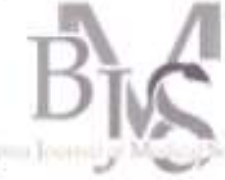

○

- 0

-

○

1. Therapeutic Chemistry Laboratory, Department of Pharmacy, University of Sidi Bel-Abbes, 22000, Algeria.

\section{Central Laboratory,}

University Hospital Center of Sidi Bel-Abbes, 22000, Algeria.

3. Research in Pharmaceutical Development Laboratory, Pharmacovigilance Department, University Hospital Center $1^{\text {st }}$ November, University of Oran, 31000, Algeria.

4. General Directorate of Scientific Research and Technological Development (DGRSDT), Algiers, Algeria.

Corresponding author : Derouicha MATMOUR drmatmour24@hotmail.fr

DOI : $\underline{\text { https://doi.org/10.48087/ }}$ BJMSoa.2020.7201

Received : June 03, 2020

Accepted : September 09, 2020

Published : November 09, 2020

This is an open access article distributed under the terms of the Creative Commons

Attribution International License (CC BY 4.0), which permits unrestricted use, distribution, and reproduction in any medium or format, provided the original author and journal are appropriately credited.

\section{Citation :}

Matmour D, Achachi N, Mérad Y, ToumI H. Anticancer Drug Design: Development of CyclinDependent Kinase Inhibitors Using In Silico Techniques. Batna J Med Sci 2020;7(2):71-3. https://doi.org/10.48087/BJMS oa.2020.7201

\title{
Anticancer Drug Design: Development of Cyclin-Dependent Kinase Inhibitors Using In Silico Techniques
}

\author{
Conception de médicaments anticancéreux: Développement in silico \\ d'inhibiteurs de kinases cycline dépendante
}

\author{
Derouicha Matmour ${ }^{1,2,3,4 *}$, Nawel Achachi ${ }^{3,4}$, Yassine Mérad ${ }^{2,4}$, Houari Toumi ${ }^{3,4}$
}

\begin{abstract}
In mammalian cells, proliferation is controlled by the cell cycle, where cyclin-dependent kinases regulate critical checkpoints. CDK4 is considered highly validated anticancer drug target due to its essential role regulating cell cycle progression at the G1 restriction point. Our objective is designing novel CDK4 inhibitors using Structure-Based Drug Design and Quantitative StructureActivity Relationship techniques. We used bioinformatics tools and biological databases. QSAR study of CDK4 inhibitors has given us an idea on the physicochemical features of studied compounds and their correlation with the $\mathrm{IC}_{50}$ activity. The docking study has helped to highlight the molecule key elements to refine in order to get a more potent compound of CDK4.The Molecule under the code 21366124 which has the low $\mathrm{IC}_{50}=3$ nmole shows the most binding affinity with score value of $\Delta G=-9,8$ $\mathrm{kcal} / \mathrm{mol}$. As prospects, it would be very interesting to synthesize this drug candidate and to test its inhibitory activity on cell culture of breast cancer
\end{abstract}

Keywords: CDK4, Inhibitors, QSAR, SBDD, Docking, Breast cancer.

\section{INTRODUCTION}

The strategy of Structure-Based Drug Design (SBDD) has accelerated many drug discovery projects and already yielded several promising anticancer leads acting towards different targets, including Cyclin-Dependent-Kinases (CDKs) [1].

The Quantitative Structure-Activity Relationship (QSAR) techniques have been widely used for predicting a broad spectrum of biological activities [2].

Protein kinases are key enzymes in regulatory signals of major physiological functions. Dysfunction of these proteins is often associated with diseases such as cancer, inflammatory or neuro-degenerative diseases. That's why protein kinases have become essential therapeutic targets [3].

Sustained proliferative capacity is a hallmark of cancer. In mammalian cells, proliferation is controlled by the cell cycle, where CDKs regulate critical checkpoints. CDK4 is considered highly validated anticancer drug target due to its essential role regulating cell cycle progression at the G1 restriction point [4].

\section{RÉSUMÉ}

Dans les cellules de mammifères, la prolifération est contrôlée par le cycle cellulaire, où les kinases dépendantes de la cycline régulent les points de contrôle critique. La CDK4 est considérée comme étant une cible thérapeutique anticancer hautement validée en raison de son rôle essentiel dans la régulation de la progression du cycle cellulaire au point de restriction G1. L'objectif de ce travail est de concevoir de nouveaux inhibiteurs CDK4 à l'aide de techniques de conception de médicaments basées sur la structure et sur l'activité biologique. Des outils de bio-informatique et des bases de données biologiques ont été utilisés. L'étude QSAR des inhibiteurs CDK4 a donné une idée sur les caractéristiques physicochimiques des composés étudiés et leur corrélation avec l'activité $\mathrm{IC}_{50}$. L'étude d'amarrage moléculaire a permet de mettre en évidence les éléments clés de la molécule dockée afin d'obtenir un inhibiteur CDK4 plus puissant. La molécule sous le code 21366124 qui a la plus faible IC 50 = 3 nmole, s'est avérée la plus affine avec un score d'énergie $\Delta G=-9,8 \mathrm{kcal} / \mathrm{mol}$. En perspectives, il serait très intéressant de synthétiser cette molécule candidate et de tester son effet inhibiteur sur une culture cellulaire de cancer du sein.

Mots-clés : CDK4, inhibiteurs, QSAR, SBDD, Docking, Cancer du sein.

In this study, our main objective was to identify new anticancer drug candidates, using the SBDD and QSAR techniques for designing novel CDK4 inhibitors.

\section{MATERIALS AND METHODS}

The present study combines ligand-based drug design and structure-based drug design approaches.

In one hand, 2D quantitative structure activity relationship (2D-QSAR) was used to generate models from 83 compounds belonging to CDK4 inhibitors and separated to training and test sets. Validation of the QSAR model was judged by root-mean-square error (RMSE) and the correlation factor $\left(\mathrm{R}^{2}\right)$ [5-7].

In the other hand, docking studies of six inhibitors were carried to determine their binding mode into the active site of CDK4 and to interpret the efficacy of molecules that's capable to inhibit CDK4 $[8,9]$.

We used software's of SBDD and QSAR wich are based on molecular modeling techniques and in silico virtual screening $[\mathbf{9}, \mathbf{1 0}]$. 


\section{RESULTS AND DISCUSSION}

\section{2D-QSAR Study}

2D-QSAR study was performed in order to find a mathematical correlation between the structure and physicochemical properties of CDK4 inhibitors and their inhibitory activity that was expressed as PIC $_{50}\left(-\log \mathrm{IC}_{50}\right)$.

The model I showed in Figure 1 exhibited a correlation between the experimentally observed and predicted values of CDK4 inhibitors. The resultant correlation regression analysis plot showed a linear relationship in model I with RMSE $=0.2458, \mathrm{R}=0.9345$ and $\mathrm{R}^{2}=0.8733$. No molecule was an outlier in the database using MOE's plotting applications in the model. We have also verified that the model was valid with $\mathrm{R} 2$ $=0.15$ and $\mathrm{Q} 2=-0.37$ (Figure 2).

The correlation coefficient between the experimental observed and predicted value of test set compounds of inhibitors was 0,70 .

\section{traintest2.M6 (PLS), Untitled}

YPred:Comp. 3](YVar Picas (M))/YVar(YVar PIC

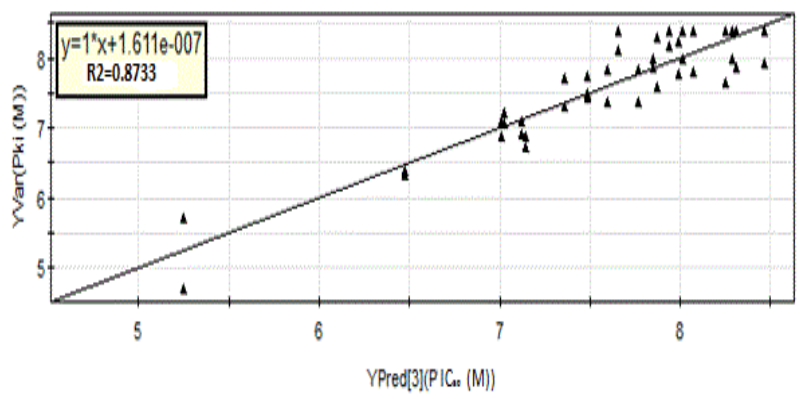

Figure 1. Linear correlation plots of 2D-QSAR.

traintest2.M6 (PLS): Validate Model

Pki (M) Intercepts: $R 2=(0.0,0.159), Q 2=(0.0,-0.374)$
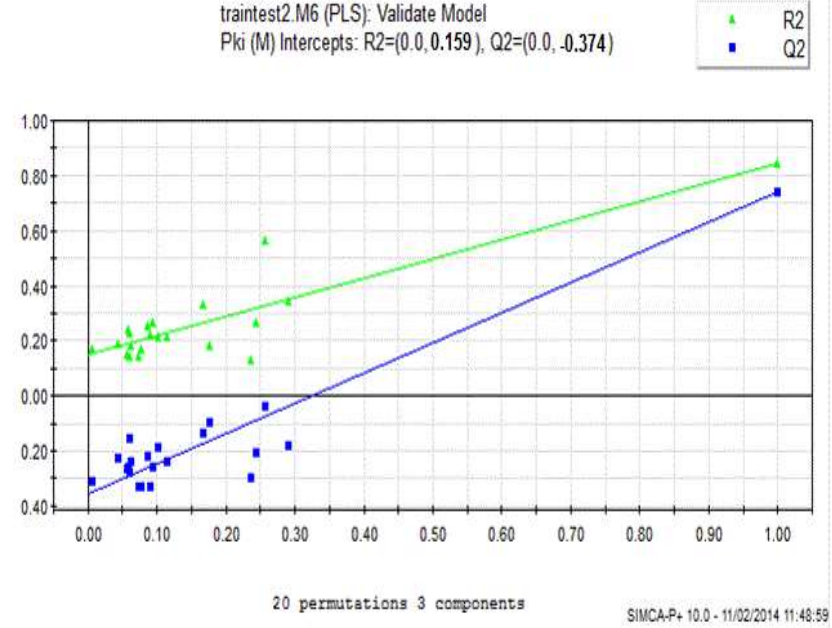

Figure 2. Model validation.

\section{Molecular Docking Study}

Figure 3 shows the 3D crystal structure of CDK4 extracted from PDB (Code: 4DHU) and Figure 4 shows the selected target site of CDK4, the magenta spheres represent where the molecular docking was focused.

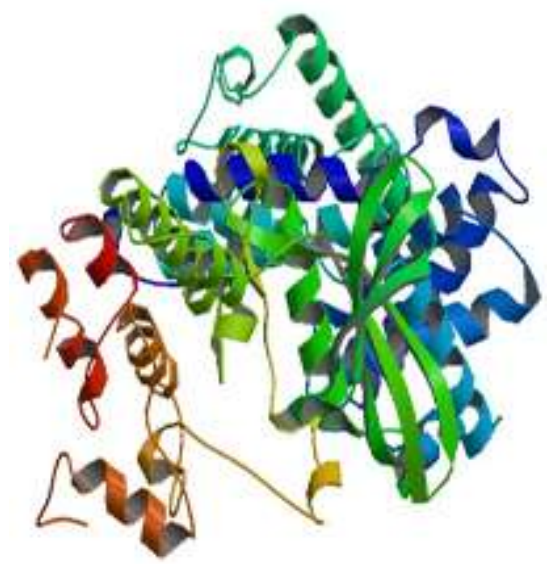

Figure 3. 3D crystal structure of CDK4.

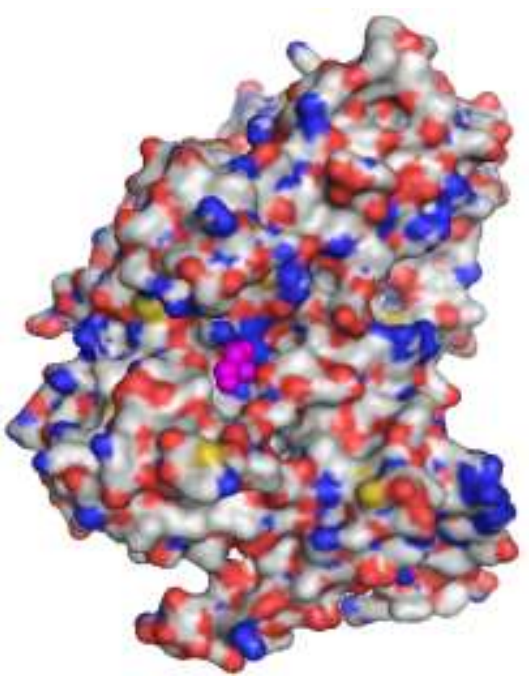

Figure 4. Selected target site of CDK4.

The Coumpond under the code 21366124 is successfully docked in the active site of CDK4. Its $\mathrm{IC}_{50}=3 \mathrm{nmole}$ and its binding energy $=-9.8 \mathrm{Kcal} / \mathrm{mol}$, therefore, it proved the most affine. It formed three hydrogen bonds with the residues: Arg136, Thr165 and Asp73 whose lengths: $3.04 \mathrm{~A}^{\circ}, 2.94 \mathrm{~A}^{\circ}$ and $2.92 \mathrm{~A}^{\circ}$. Three hydrophobic pockets formed and interaction piStacking between imidazole nucleus of ligand and pyrrolidine nucleus of L-proline amino acid (Figure 5).

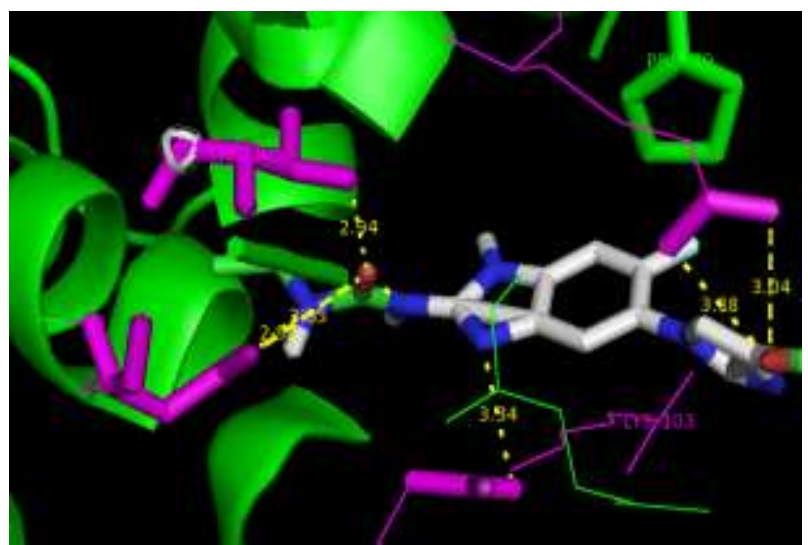

Figure 5. Interaction between CID 21366124 and CDK4. 


\section{CONCLUSION}

We have performed a structure-activity relationships study of CDK4 as potential therapeutic target. QSAR study of CDK4 inhibitors has given us an idea on the physicochemical features of studied compounds and their correlation with the $\mathrm{IC}_{50}$ activity. Furthermore, the docking study has helped to highlight the molecule key elements to refine in order to get a more potent compound of CDK4.

The molecule under the code 21366124 which has the low $\mathrm{IC}_{50}=3$ nmole shows the most binding affinity with score value of $\Delta \mathrm{G}=-9,8 \mathrm{kcal} / \mathrm{mol}$ and it presents the best interactions and energy score testifying the complex stability. As prospects, it would be very interesting to synthesize this drug candidate and to test its inhibitory activity on cell culture of breast cancer.

\section{CONFLICT OF INTEREST}

The authors declare that they have no conflict of interests.

\section{REFERENCES}

1. Cavasotto C, Orry, A. Ligand Docking and Structure-Based Virtual Screening in Drug Discovery. Current Topics in Medicinal Chemistry. 2007; 7: 1006-1014

2. Arkadiusz ZD, Tomasz A and Jorge G. Computational Methods in Developing Quantitative Structure-Activity Relation-ships (QSAR): A Review. Combinatorial Chemistry \& High Throughput Screening. 2006; 9: 213-228.
3. Sandrine Piguel, Chi Hung Nguyen, Delphine Martin, Tom Baladi and J. Aziz. Chimie des petites molécules pour le ciblage des protéines. Sondes de structures et sondes photoactivables pour les acides nucléiques et les kinases. Accessed December 09th 2018, Available at: https://studylibfr.com/doc/4594887/chimie-des-petitesmol\%C3\%A9cules-pour-le-ciblage-des-prot\%C3\%A9ines.

4. Concepción SM, Lawrence MG, María JL, Alfonso D. Cyclin dependent kinase (CDK) inhibitors as anticancer drugs. Bioorganic \& Medicinal Chemistry Letters. 2015; 25: 3420-3435.

5. Molecular Operating Environment (MOE). Integrated computer-aided molecular design platform for small molecule and biological therapeutics. Common platform for Chemists, Biologists and Crystallographers. Available at: https://www.chemcomp.com/Products.htm [Accessed $15^{\text {th }}$ July 2018].

6. CanSAR Database. Available at: https://cansarblack.icr.ac.uk/ [Accessed $15^{\text {th }}$ July 2018].

7. Gramatica P. Principles of QSAR Models Validation: Internal and External. QSAR \& Combinatorial Science. 2007; 26: 694-701.

8. Trott $\mathrm{O}$ and Olson AJ. AutoDock Vina: Improving the Speed and Accuracy of Docking with a New Scoring Function, Efficient Optimization, and Multithreading. Journal of Computational Chemistry. 2010; 31: 455-461.

9. Rohini R, Souda PR, Vishwanath R and al. Selective ATP competitive leads of CDK4: Discovery by 3D-QSAR pharmacophore mapping and molecular docking approach. Computational Biology and Chemistry. 2017;71: 224229.

10. Anupama Pandrangi. Molecular Docking and QSAR Studies on CDK4 Inhibitors Using In Silico Techniques. Journal of Pharmaceutical and Scientific Innovation. 2014;3(2):164-169.

This article was published in the "Batna Journal of Medical Sciences" BJMS, the official organ of the « Association pour la Recherche Pharmaceutique et l'Enrichissement des Connaissances - Batna »

The content of the Journal is "Open Access" and allows the reader to download and use the content for personal or educational purposes without requesting permission from the publisher/author.

Advantages of publishing in BJMS :

- Open access : once published, your article is available for free download

- Free submission: no submission fee, unlike most "Open Access" journals

- Possibility to publish in 3 languages : French, English, Arabic

- Quality of proofreading: geographically independent proofreaders/reviewers, respecting anonimity, to guarantee the neutrality and quality of the manuscripts.

For more information, contact BatnaJMS@gmail.com or log on to the journal's website: www.batnajms.net 